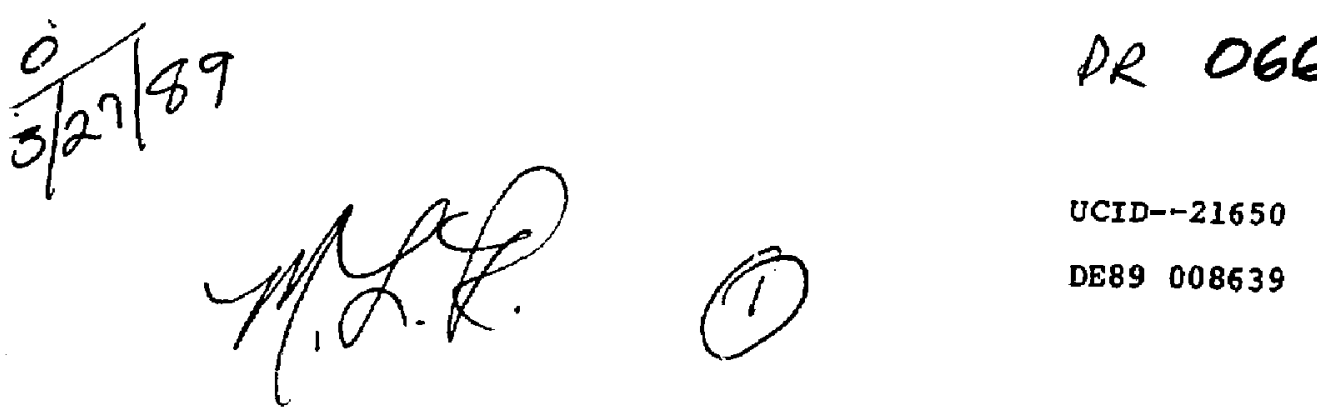

Linear Plasma-Based Tritium Production Facility

F.H. Coensgen, A.H. Futch, and A.W. Molvik

This is an informal report inteided primarily for internal or limited external distribution. The opinions and conclusions stated are those of the author and may or may not be those of the Iaboratory.

Work performed under the asspices of the U.S. Department of Energy by the hawtence Livermore Natianal Laboratary under Conlact W-7405-Eng-18.

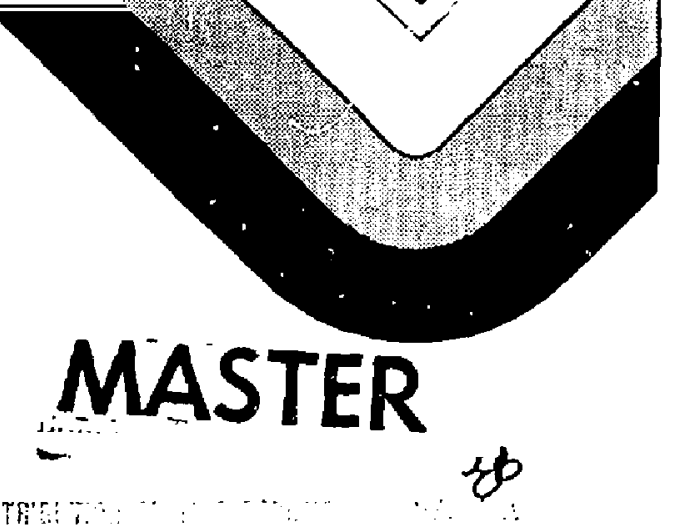




\section{Linear Plasma-Based Tritium Production Facility}

F. H. Coensgen, A. H. Futch, and A. W. Molvik

\section{Concept}

A schematic diagram of a $5 \mathrm{~kg} / \mathrm{yr}$ tritium breeder is shown in Figure 1. The system is simply a long fully fontzed dense tritium plasma column confined radially by a linear magnetic field. An intense flux of 14-MeV neutrons is produced by transverse injection of $150-\mathrm{keV}$ deuterons into the tritfum plasma, which is sufficlently dense to essentially stop all of the beams. The trapped deuterlum lons collide with tritium target fons malntalning the D-T fuston reaction rate. The energetic ions are confined radially by the magnetic ffeld and longltudinally by magnetic mirrors. Through collisions the hot lons lose thelr energy to the plasma electrons, which in turn Ionize and heat the tritium component and thus maintain the plasma target. All injected power is trensported by electron thermal conduction along a solenoldal guide fleld to end reglons where it is absorbed in neutral trltium gas at high pressure. The high-density tritium serves two functions: it is the source of tritium for the plasma column, and 1t prevents the erosion of the end walls by the hot plasma column. Ions entering the end chambers are cooled and either recombined with electrons of reach the walls with energles below the thresholds for sputtering. Power loading at the walls is reduced to values that can be handled by conventional cooling technology. In principle part of the energy can be recovered to reduce power consumption and thus lower operating costs. This option has not been evaluated and is not included in the estlaateg given below.

The concept presented here is an adaptation of a recently completed conceptual destgn ${ }^{1}$ of a compact high-fluence $D-T$ neutron source for accelerated end-of-life testing of fuston reactor materials. Although this preliminary assessment serves to 1llustrate the main features of a linear plasma-based trittum breeder, it is not necessarily an optimized design. We 


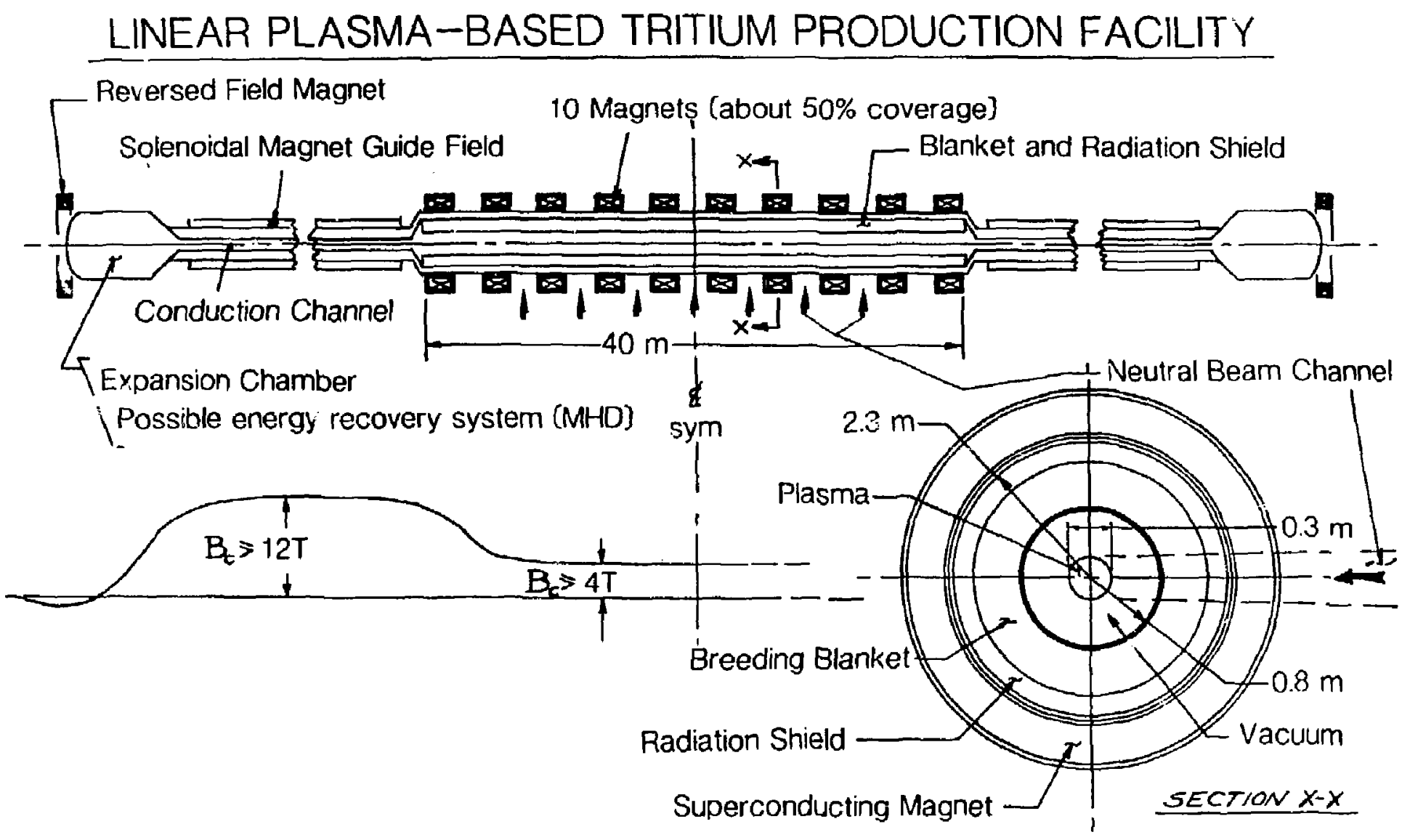


belleve that proper design cholces for the breeder application will certalnly reduce costs, perhaps as much as a factor of two. We also point out that Q (the ratio of fusion power produced to power input to the plasma) increases with system length and that the cost per $\mathrm{kg}$ of $\mathrm{trit}$ ium decreases for longer systems with higher output (see Table 1). In earlier studies of linear two-component plasma systems, $Q$ values as high as three were predicted. At this level of performance and with energy recovery, operaring power requirements of the breeder could approsch zero.

Similar values of $Q$ are obtained in recent Soviet studies of long linear mitror system. They discuss development of these systems for production of fissile fuel and tritium.

\section{Phystes and Technical Basis}

The physics and technology data base for the breeder design has been developed in the magnetic fusion program over a considerable time span and has extensive veriflcation. This data base was summarized by Molvik ${ }^{2}$. The breeder plasma design closely resembles that of the 2 XIIB experiment, whleh was operated at LLNL from October 1973 to October 1978 and demonstrated stable operation of a two-component plasma. ${ }^{3}$ Notable among the achlevements in that experiment was the demonstration of stable confinement of high- $\beta$ plaswas, which are needed for economic operation of the breeder. $\beta$ is the ratio of plasma energy density to magnetic fleld energy density. Also 2XIIB experiments confirmed the theorecically derived conditions for control of high-frequency fluctuations (1.e., mirror mode microinstabilities). Recent work on MHD stability in axisymetric systems is reported by Molvik et al. ${ }^{4}$ Much of this work was carried out in a USIUSSR callaborative effort on the Sovlet Gas Dynamic Trap experiment at the Institute for Nuclear Physics, Novosibirsk, USSR.

AlI technologies needed for the tritfum breeder are within the state of the art. The $150-\mathrm{keV}$ neutral beams w1ll be demonstrated on JET in the 
spring of 1989 for a duration of $10-20 \mathrm{sec}$. All components are essentially at steady state. A longer lived cathode is desirable since present. fllaments are estimated to have a 2-week lifetime in steady state operation. Superconducting magnets of $12-T$ flelds were demonstrated during MFTF acceptance tests. The blanket technology is based on existing designs.

\section{Development}

We belleve that a tritfum breeder based on a linear plasms system could be an alternative for production facility, and we recommend a serlous design effort be initiated at this time. To make the transition from the existing physics and technology facilities to safe, rellable, continuously operating production facility as soon as posslble, a test section of a fullsized breeder could be initlated following the design study. Th1s test section would first be run using hydrogen to avold neutron radiation and activation problems durfing development of contlnuous operation of neutralbeam systems, power rovval and/or energy recovezy, and remote-controlled operation and malntenance. All safety aspects of the facllity would also be perfected and demonstrated in the hydrogen operation phases. Once rellability and safety are demonstrated, the test section would be operaced as a tritium breeder to perfect blanket technology and tritium extraction. Based on our cost analysis of the intense neutron surce, we estimate the construction cost of a 200-MW test section to be approximately $\$ 250 \mathrm{M}$.

In more conservative approach to develop the breeder, the integrated physics design and power handing techniques could be verifled first, using lower energy beams at lower power. Based on previous estimates, a pulsed 20MW test faclifty could be constucted at LLNL using existing equipment for approximately $\$ 10 \mathrm{M}$ in about 1 year. 


\begin{tabular}{|c|c|c|}
\hline & $2000 \mathrm{~m}$ & $40 \mathrm{~m}$ \\
\hline Unit size (kg T/yr) & 18.0 & 5.0 \\
\hline Capital costs $\left(1 \times 10^{9} \mathrm{~s}\right)$ & 2.5 & $1.6^{\star}$ \\
\hline Power required (MWe) & 2000.0 & 1400.0 \\
\hline $\begin{array}{l}\text { Operating and maintenance } \\
\left.\text { costs ( } 1 \times 10^{6} \$\right)\end{array}$ & 550.0 & 350.0 \\
\hline $\begin{array}{l}\text { Number of units to } \\
\text { produce } 5 \mathrm{~kg} \mathrm{T/yr}\end{array}$ & 0.28 & 1.0 \\
\hline Q & 0.7 & 0.3 \\
\hline
\end{tabular}

*Blanket and tritium recovery system not included.

\section{Cost Bas1s}

To estimate construction and operaring costs, we note that the size of the system is essentially proportional to the required power, which is estimated as outlined below. Costs are then obtained by scaing our estimates for the intense neutron source. For the $5-\mathrm{kg} / \mathrm{yr}$ factilty, the estitnated construction cost is $\$ 1.6$ billion without tritium breeding 
blankets or extraction factlicles. Opereting coses are strongly dependent on power costs and energy recovery.

As stated above, the dominace hear loss is the electron thermal conduction from the hot plasma core to the gas target in each end cell. For a cylindrical plasma column, this power flow is given by

$$
\text { Flow power }=\left(4 \prod^{2} / 1_{c}\right) \int \mathrm{KdT}_{e}
$$

where $K=9.3 \times 10^{13}\left(\mathrm{~T}_{e}\right)^{5 / 2} \mathrm{~W} / \mathrm{m}-\mathrm{keV}$ with $\mathrm{T}_{e}$ expressed in keV. The coefficlent of thermal conductivity was derived by Spitzer and Harm. 5 For a gaussian radial profile, the fuston power is

$$
\text { Fustor power }=n_{h} n_{w}\langle\sigma v\rangle \text { Eella }^{2} 1_{h} / 2
$$

where $n_{h}$ and $n_{w}$ are the peak densities of the hot and warm plastaa, respectively; $1_{h}$ is the length of the plasma column occupied by the hot lons; and $a$ is the radial e-folding length of the plasma. $Q$ is defined as

$$
Q=\text { fusion power/flow power }=1.47 \times 10^{-24}(\sigma v\rangle n_{w} n_{h}\left(1_{c}{ }^{1}{ }^{R}\right) /\left(T_{e}\right)^{7 / 2}
$$

for cgs units except $\mathrm{I}_{\mathrm{e}}$ is expressed in keV. For a neutral-beam efficlency of $30 z$, the tritium production race becomes

$$
M_{t} / E=12.7 Q \mathrm{~kg} / \mathrm{GW}-\mathrm{yr}
$$

\section{References}

1. F. H. Coensgen, T. A. Casper, D. L. Correll, C. C. Damm, A. H. Futch, B. G. Logan, A. W. Molvik, R. H. Bulmer, "A D-T Neutron Source for Fusion Materlals Testing," Lawrence Llvermore National Laboratory, Ifvermore, CA, UCRL-97280, Rev. 1 (1987). 
2. A. W. Molvik, "Sumary of Mirror Experiments Relevant to Besm-Plasma Neutron Sources," Lawrence Livertnore National Laboratory, Livermore, CA, UCID-21532 (1988).

3. W. C. Turner, J. F. Clauser, F. H. Coensgen, D. L. Correll, W. F. Cummins, R. P. Freis, R. K. Goodman, A. I. Hunt, T. B. Kalser, G. M. Melin, W. E. Nexsen, T. C. Stmonen, and B. W. Stallard, Nicl. Fuston 19, 1011 (1979).

4. T. A. Casper, A. W. Molvik, P. Bagryansky, et al., "Fluctuation Measurements Study of the MHD Stabil1ty of the Gas Dynamic Trap," presented at the 13ih Annual Meeting, Division of Plasma Physics, Hollywood, FL, Lawrence Livermore National Laboratory, Livermore, CA, UCRL-99587 (1988).

5. I. Spitzer and R. Harm, Phys. Rev. 89, 977 (1953).

fhe $8940 /$ prs

$2 / 24 / 89$ 